\title{
BRIQUETTES QUALITY PRODUCED WITH THE MACAUBA EPICARP (Acrocomia aculeata) AND Pinus sp. WOOD
}

\author{
Sarah Esther de Lima Costa ${ }^{2 *} \odot$, Rosimeire Cavalcante dos $\operatorname{Santos}^{3} \odot$, Renato Vinícius Oliveira Castro ${ }^{4} \odot$, Ana \\ Flávia Neves Mendes Castro ${ }^{4}{ }^{\circ}$, Mateus Alves de Magalhães ${ }^{5}{ }^{\odot}$, Angélica de Cássia Oliveira Carneiro ${ }^{\circ}$, Cyn- \\ thia Patrícia de Sousa Santos ${ }^{7}$, Izabelle Rodrigues Ferreira Gomes ${ }^{7}{ }^{\circ}$ and Sofia Maria Gonçalves Rocha ${ }^{8}$ () \\ ${ }^{1}$ Received on 17.08.2018 accepted for publication on 07.02.2019. \\ ${ }^{2}$ Universidade Federal do Rio Grande do Norte, Programa de Pós-Graduação em Ciências Florestais, Macaíba, RN - Brasil. E-mail: \\ <sarahcostaa@yahoo.com.br>. \\ ${ }^{3}$ Universidade Federal do Rio Grande do Norte, Unidade Acadêmica Especializada em Ciências Agrárias., Macaíba, RN- Brasil. E-mail: \\ $<$ meire_caico@yahoo.com.br>. \\ ${ }^{4}$ Universidade Federal de São João Del-Rei, Departamento de Engenharia Florestal, Sete Lagoas, MG- Brasil. E-mail: < castrorvo@ymail. \\ com> and <anaflaviacastro@ufsj.edu.br>. \\ ${ }^{5}$ Universidade Federal de Viçosa, Programa de Pós-Graduação em Ciências Florestais, Viçosa, MG - Brasil. E-mail: <mateusmagalhaes91@ \\ gmail.com>. \\ ${ }^{6}$ Universidade Federal de Viçosa, Departamento de Engenharia Florestal, Viçosa, MG - Brasil. E-mail: <cassiacarneiro1@gmail.com>. \\ ${ }^{7}$ Universidade Federal Rural do Semi-Árido, Programa de Pós-Graduação em Fitotecnia, Mossoró, RN - Brasil. E-mail: <cynthiapss@live. \\ com> and <izabelle.rodriguesferreira@gmail.com>. \\ ${ }^{8}$ Universidade Federal do Espírito Santo, Programa de Pós-Graduação em Ciências Florestais, Jerônimo Monteiro, MG - Brasil. E-mail: \\ <sofiamaria.r@hotmail.com>. \\ *Corresponding author.
}

\begin{abstract}
The macaúba palm (Acrocomia aculeata) is a palm-seed-oil producing tree of great economic value for its high productivity, and the broad range of possible uses for the different parts of the plant. This palm is one of the most promising species for the production of biodiesel, however, its use generates large amounts of waste. The aim of this work is to produce and evaluate the quality of briquettes made from the epicarp of the macaúba palm, in association with the waste of the Pinus sp. For the characterization of the residues, the following analyses were carried out: bulk density, immediate chemical composition, and higher calorific value. Different treatments were adopted in the production of the briquettes, namely: T1 (100\% macaúba palm), T2 (75\% macaúba palm $+25 \%$ pine), T3 (50\% macaúba palm $+50 \%$ pine), T4 (25\% macaúba palm $+75 \%$ pine) and T5 $(100 \%$ pine $)$. The briquettes were produced at a pressure of $1000 \mathrm{PSI}$, and at a temperature of $120-130{ }^{\circ} \mathrm{C}$, press and cooling times of 5 minutes, and an average humidity of $9.88 \%$ for the macaúba palm and $8.00 \%$ for the Pinus. In order to qualify the briquettes' dimensions, the following were evaluated: apparent density, rupture load, lower calorific value, useful calorific value and energy density. In general, mixing at least 50\% macaúba epicarp is recommended to produce briquettes, as this material provides increased strength and energy density to the product.
\end{abstract}

Keywords: Biomass energy; Quality of briquettes; Agroforestry residues.

\section{QUALIDADE DE BRIQUETES PRODUZIDOS COM EPICARPO DE MACAÚBA (Acrocomia aculeata) E MADEIRA DE Pinus sp.}

RESUMO - A macaúba (Acrocomia aculeata) é uma palmeira oleaginosa de alto valor econômico pela sua grande produtividade e pelas amplas possibilidades de aproveitamento das diferentes partes da planta. Esta palmeira é uma das espécies mais promissoras para a produção de biodiesel, e, durante o seu uso, há geração de grande quantidade de resíduos. O objetivo deste trabalho foi produzir e avaliar a qualidade de briquetes confeccionados com epicarpo da macaúba, em associação aos resíduos da madeira de Pinus sp. Para caracterização dos resíduos foram realizadas as análises: densidade a granel, composição química imediata e poder calorífico superior. $\mathrm{Na}$ produção de briquetes foram adotados diferentes tratamentos, sendo T1 (100\% Macaúba), T2 (75\% Macaúba + 
25\% Pinus), T3 (50\% Macaúba + 50\% Pinus), T4 (25\% Macaúba + 75\% Pinus) e T5 (100\% Pinus). Os briquetes foram produzidos à pressão de $1000 \mathrm{PSI}$, temperatura de $120-130^{\circ} \mathrm{C}$, tempos de prensagem e resfriamento de 5 minutos e umidade média de $9.88 \%$ para a macaúba e $8.00 \%$ para o Pinus. Para qualificar os briquetes avaliou-se as dimensões, densidade aparente, carga de ruptura, poder calorífico inferior, poder calorífico útil e densidade energética. De modo geral, recomenda-se a mistura de pelo menos $50 \%$ de epicarpo de macaúba para a produção de briquetes, pois este material confere maior resistência e densidade energética ao produto.

Palavras-Chave: Energia da biomassa; Qualidade dos briquetes; Residuos agroflorestais.

\section{INTRODUCTION}

The contribution of biomass to the Brazilian energy matrix accounted for $23.8 \%$ of total renewable energy (EPE, 2015). Given this scenario, steady growth, and diversification of the energy matrix is projected up to the year 2030, such that a considerable increase in the use of renewable sources can be envisaged, including the use of agricultural and forestry waste (Tolmasquim, 2007).

Notably, a great quantity and variety of forest waste is generated annually by various forest-based industries, such as the generation of waste in the supply chain of pine sawn, to the tune of $75 \%$. In other words, only $25 \%$ of the total volume of a tree is placed on the market in the form of boards, rafters, slats, etc. (Mendes et al., 2004). However, the pine forest is intensively used in other activities, and has established its production chain, such as laminating industry, MDF, pulp and paper, boards and sheets.

The biodiesel production chain is among the diverse agricultural residues, and the saccharine and oleaginous species stand out as promising sources of vegetable oil for this activity. However, these species generate large amounts of waste. Among these species, the macaúba palm - an oleaginous palm tree native to Brazil, with high oil contents in its pulp and almond - and its epicarp, are usually discarded during fruit processing (Motoike, 2013).

Consequently, this prolific generation of residues from agroforestry biomass in Brazil can cause environmental problems, such as the silting and contamination of waterways, the use of large spaces in industries, and an increase in air pollution as it is burned (Protásio et al., 2011).

The transformation of waste into biofuels is an interesting alternative to combating these problems, since it provides increased energy efficiency, and transport quality, on the one hand, and the reduction of costs on the other. Currently, there are several technologies available for the conversion of residues to biofuels (Evaristo et al., 2016), namely, in the form of pellets and briquettes.

Briquettes are solid biofuels produced under controlled temperatures and pressures. The briquetting process is a suitable method for reusing materials generated by agroforestry. In addition, as a low moisture material, its biodegradability is reduced, as well as the energy density of the compacted product (Silva, 2007).

Accordingly, Pinus residue briquettes are already sold on the market, however being an expensive material, it is necessary to study the quality of pine residue briquettes, associated with other sources that promote better compaction of this material, in addition to lower manufacturing costs.

Within this context, this study aimed to produce and evaluate the quality of briquettes made from the epicarp of the macaúba palm in association with rates of waste of Pinus sp.

\section{MATERIAL AND METHODS}

The research was developed at the Wood Panel and Energy Laboratory (LAPEM), Department of Forestry Engineering, Federal University of Viçosa (UFV), in Viçosa / MG - Brazil.

The fruits of the macaúba palm were donated by the fruit sector of the UFV. These, after being harvested, were placed in an oven at $60^{\circ} \mathrm{C}$ for 24 hours, in order to facilitate removal of the epicarp.

Pine wood waste from the UFV sawmill was put into oven at $60^{\circ} \mathrm{C}$, prior to drying, to reduce its moisture content, facilitating the milling. After obtaining the materials, they were reduced to particles in a hammer mill and classified in sieves with a mesh of $2 \mathrm{~mm}$, to suit the characteristics of the matrix of the briquetting, with a diameter of $3 \mathrm{~cm}$ and a $15 \mathrm{~cm}$ column.. 
After grinding, the particles were dried in an oven and the moisture, dry basis, was determined by means of a MB35 Halogen scale. The pine residue with $8 \%$ moisture content was used and the macaúba epicarp had a content equal to $9.88 \%$.

For the study of the chemical analysis and calorific value, the biomasses were again crushed in a Wiley lab type mill. The particles were sieved through the 40 mesh sieve and retained in the 60 mesh sieve (ASTM, 1982).

The bulk density was performed using a plastic beaker with a volume of $1 \mathrm{~L}$. The methodology, adapted from the methodology described in DIN EN 15103 (2010), was estimated using the formula: $\mathrm{DG}=\mathrm{M} / \mathrm{V}$, where:

$$
\begin{aligned}
& \mathrm{DG}=\text { bulk density }\left(\mathrm{kg} / \mathrm{m}^{3}\right) \\
& \mathrm{M}=\text { mass inserted into beaker }(\mathrm{kg}) \\
& \mathrm{V}=\text { beaker volume }\left(\mathrm{m}^{3}\right) .
\end{aligned}
$$

The determination of the immediate chemical composition, which indicates the percentages of volatile materials, ash and fixed carbon, followed the norm NBR 8112 (ABNT, 1986).

The upper calorific value (PCS) was determined according to the ABNT NBR 8633 (1984), using an adiabatic calorimetric pump.

The useful calorific value (PCU) was estimated by the function of the humidity and the lower calorific value according to the following formula:

$$
\mathrm{PCU}=[\mathrm{PCI} \times(1-\mathrm{U})]-600 \mathrm{U}
$$

Being:

$$
\begin{aligned}
& \text { PCU = Useful Calorific value (kcal / kg); } \\
& \mathrm{U}=\text { Dry basis moisture (\%); } \\
& \text { PCI = Lower calorific value ( } \mathrm{kcal} / \mathrm{kg}) .
\end{aligned}
$$

The lower calorific value (ICP) was estimated according to the following formula:

$$
\begin{gathered}
\text { PCI }=\text { PCS }-[600(9 \mathrm{H} / 100)], \text { considering } 6 \% \\
\text { hydrogen. }
\end{gathered}
$$

The briquettes were produced in a Lippel brand, briquetting machine, model LB-32. The mass of 18 grams was established for the production of each briquette, with humidity varying between 8 and 10\%. For this, the briquettes were manufactured under the following proportions: T1: 100\% macaúba; T2: 75\% + 25\% macaúba Pinus sp.; T3: 50\% + 50\% macaúba Pinus sp.; T4: 25\% + 75\% macaúba Pinus sp.; T5: 100\% Pinus sp.

The briquette was set to work at $120-130^{\circ} \mathrm{C}$ and 1000 PSI pressure for all treatments. The pressing and cooling times were 5 minutes each, used in all treatments.

The apparent density of the briquettes was determined by the mercury immersion method $(\mathrm{Hg})$ and the displaced volume was obtained, according to ABNT (2003) NBR 11941.

The energy density of the residues was defined as the product of the values of apparent density and the useful calorific value, from the following equation:

$$
\mathrm{D}_{\mathrm{n}}=\mathrm{D}_{\text {apparent }} \times \mathrm{PCU}
$$

Where: $\mathrm{D}_{\mathrm{n}}=$ energy density in $\mathrm{MJ} / \mathrm{kg}$

$$
\begin{aligned}
& \mathrm{D}_{\text {apparent }}=\text { Apparent density in } \mathrm{kg} / \mathrm{m}^{3} \\
& \mathrm{PCU}=\text { useful calorific value in } \mathrm{MJ} / \mathrm{kg}
\end{aligned}
$$

To evaluate the bursting load of the briquettes, a universal test machine, model LOSENHAUSEN was used. Hence, force on a flat side of the briquette, through piston with test speed of $6.0 \mathrm{~mm}$ min was applied. This procedure is in accordance with the methodology expressed in the NBR 7190 of ABNT (1997), since there are no specific standards for tests on briquettes.

The dimensions of the briquettes, diameter and length were obtained with the aid of a pachymeter. In this sense, the experiment was analyzed according to a completely randomized design, with five treatments (Table 1) and five replicates (briquettes).

Table 1 - Treatments used in the manufacture of briquettes. Tabela 1 - Tratamentos empregados na confecção dos briquetes

\begin{tabular}{cc}
\hline Treatments & Proportions \\
\hline T1 & $100 \%$ Macaúba \\
T2 & $75 \%+25 \%$ Pinus Macaúba \\
T3 & $50 \%+50 \%$ Pinus Macaúba \\
T4 & $25 \%+75 \%$ Pinus Macaúba \\
T5 & $100 \%$ Pinus \\
\hline
\end{tabular}

Revista Árvore 2019;43(5):e430501 
Data were submitted to the Lilliefors tests to test normality, and Cochran to test the homogeneity of the variances. Afterwards, the analysis of variance was performed by the $\mathrm{F}$ test, and the means were compared by the Tukey test. The significance level of $5 \%$ was always considered. Statistical analyses were performed with the help of the STATISTICA 8.0 program (Statsoft, INC, 2009).

Then, the breaking load variables, bulk density, content, bulk density, energy density, length and diameter were adjusted to the quadratic model $\mathrm{Y}=\beta_{2}$ $* \mathrm{X}^{2}+\beta_{1} * \mathrm{X}+\beta_{0}+\varepsilon$, Y being the measured variable briquette quality and $X$ percentage of the macaúba epicarp the mixture, with the objective of identifying the behavior of variables compared to the percentage of the macaúba epicarp mixed pine.

The equations were evaluated by the $\mathrm{F}$ test and the parameters by the $t$ test. The significance level of 5\% was always considered using Excel 2007.

\section{RESULTS}

\subsection{BIOMASS PROPERTIES}

Table 2 shows the characteristics of the particles macaúba epicarp and Pinus sp. studied in their different proportions. It was observed a significant effect on the wastes of the macaúba epicarp in relation to Pinus sp. for bulk density $\left(\mathrm{kg} / \mathrm{m}^{3}\right)$, ash content (\%) and upper calorific value ( $\mathrm{kcal} / \mathrm{kg})$. The bulk density of the macaúba epicarp was $401.57 \mathrm{~kg} / \mathrm{m}^{3}$ and Pinus sp. waste was $186.60 \mathrm{~kg} / \mathrm{m}^{3}$, being considered potentially lower.

It was observed that the macaúba epicarp had an ash content $(3.8 \%)$ higher than pine wood $(0.44 \%)$.

Table 2 - Mean values of biomass properties used to produce briquettes.

Tabela 2 - Valores médios das propriedades das biomassas utilizadas para produção dos briquetes

\begin{tabular}{lcc}
\hline \multirow{2}{*}{ Proprieties } & \multicolumn{2}{c}{ Waste } \\
\cline { 2 - 3 } & Macaúba epicarp & Pinus $\mathrm{sp}$. \\
\hline D. Bulk $(\mathrm{kg} / \mathrm{m} 3)$ & $401.57 \mathrm{a}$ & $186.60 \mathrm{~b}$ \\
MV $(\%)$ & $82.90 \mathrm{a}$ & $89.47 \mathrm{a}$ \\
CF $(\%)$ & $13.3 \mathrm{a}$ & $10.5 \mathrm{a}$ \\
CZ $(\%)$ & $3.8 \mathrm{a}$ & $0.44 \mathrm{~b}$ \\
PCS $(\mathrm{kcal} / \mathrm{kg})$ & $4863 \mathrm{~b}$ & $5088 \mathrm{a}$ \\
\hline
\end{tabular}

D. Bulk: Bulk density MV: content of volatile materials. CF: Fixed carbon content. CZ: ash content. PCS: Higher calorific value. The use of the same letters between residues (lines), for the same variable, did not differ significantly by the Tukey test $(p=0.05)$.
There were no significant interactions between volatile materials and fixed carbon content for the two studied biomasses. Statistical differences were verified between the fixed carbon content for the two biomasses studied.

The values of the upper calorific value for epicarp macaúba and Pinus sp. correspond to $4863 \mathrm{kcal} / \mathrm{kg}$ and $5088 \mathrm{kcal} / \mathrm{kg}$, respectively.

\subsection{PROPERTIES OF BRIQUETTES}

Table 3 lists the mean diameters $(\mathrm{mm})$ length $(\mathrm{mm})$ apparent density $\left(\mathrm{g} . \mathrm{cm}^{-3}\right)$, lower calorific value $(\mathrm{kcal} /$ $\mathrm{kg}$ ), useful calorific value ( $\mathrm{kcal} / \mathrm{kg}$ ) and energy density $(\mathrm{MJ} / \mathrm{kg})$ of the briquettes depending on the treatments.

There was a significant effect of adding macaúba epicarp for the manufacture of briquettes in combination with wood Pinus sp -- for the parameters diameter and length. It is observed that as the proportion of macaúba epicarp increased, the dimensions of the briquettes decreased due to the higher density of the epicarp.

In general, there is a tendency to increase the apparent density with the increase of the epicarp percentage in the composition of the briquettes particles.

The lower calorific value differed significantly for the two treatments analyzed, with Treatment 5 (100\% pine wood) with higher results, due to the higher value found for higher calorific value $(5088 \mathrm{kcal} / \mathrm{kg})$.

It was observed that there were significant differences between the materials for this variable, indicating a higher value for the macaúba epicarp.

The bursting load or compressive strength of the briquettes is important in the evaluation of the physical structure of these materials in relation to the impacts suffered during storage, transport, handling and stacking. Figure 1 shows the average values of the bursting load of the briquettes as a function of the percentage of macaúba epicarp. There was a significant effect of the addition of the macaúba epicarp to the composition of the briquettes.

\section{DISCUSSION}

It is observed that there was a significant difference for the different proportions, indicating that the biomasses with greater proportions of 
Table 3 - Mean values of diameters $(\mathrm{mm})$ length $(\mathrm{mm})$ apparent density $\left(\mathrm{g} . \mathrm{cm}^{-3}\right)$, lower calorific value $(\mathrm{kcal} / \mathrm{kg})$, useful calorific value $(\mathrm{kcal} / \mathrm{kg})$ and energy density $(\mathrm{MJ} / \mathrm{kg})$

Tabela 3 - Valores médios de diâmetros $(\mathrm{mm})$, comprimentos $(\mathrm{mm})$, densidade aparente $\left(\mathrm{g} . \mathrm{cm}^{-3}\right)$, poder calorifico inferior $(\mathrm{kcal} / \mathrm{kg})$, poder calorifico útil ( $\mathrm{kcal} / \mathrm{kg})$ e densidade energética $(\mathrm{MJ} / \mathrm{kg})$

\begin{tabular}{lccccc}
\hline Properties & \multicolumn{4}{c}{ Treatments } \\
\cline { 2 - 6 } & $\mathrm{T} 1$ & $\mathrm{~T} 2$ & $\mathrm{~T} 3$ & $\mathrm{~T} 4$ & $\mathrm{~T} 5$ \\
\hline Diameter $(\mathrm{mm})$ & $31.8 \mathrm{~b}$ & $34.5 \mathrm{a}$ & $34.8 \mathrm{a}$ & $34.6 \mathrm{a}$ & $34.2 \mathrm{a}$ \\
Length $(\mathrm{mm})$ & $20.1 \mathrm{~b}$ & $22.9 \mathrm{a}$ & $23.0 \mathrm{a}$ & $23.3 \mathrm{a}$ & $23.0 \mathrm{a}$ \\
Apparent density $\left(\mathrm{g} \cdot \mathrm{cm}^{-3}\right)$ & $1.13 \mathrm{a}$ & $1.09 \mathrm{ab}$ & $1.08 \mathrm{~b}$ & $1.07 \mathrm{~b}$ & $1.07 \mathrm{~b}$ \\
Lower calorific value $(\mathrm{kcal} / \mathrm{kg})$ & $4539 \mathrm{~b}$ & - & - & - & $4764 \mathrm{a}$ \\
Useful calorific value $(\mathrm{kcal} / \mathrm{kg})$ & $4174.5 \mathrm{~b}$ & - & - & - & $4321.1 \mathrm{a}$ \\
Energy density $(\mathrm{MJ} / \mathrm{kg})$ & $19.73 \mathrm{a}$ & - & - & - & $9.40 \mathrm{~b}$ \\
\hline
\end{tabular}

Same letters between residues (lines), for the same variable, did not differ significantly by the Tukey test ( $p=0.05$ ).

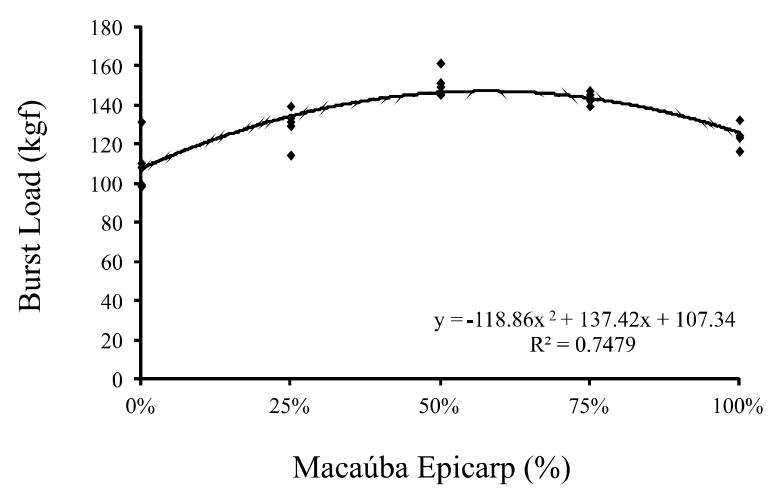

Figure 1 - Mean values of the burst load (Kgf) of the briquettes as a function of the percentage (\%) of macaúba epicarp.

Figura 1 - Valores médios da carga de ruptura (Kgf) dos briquetes em função do percentual (\%) de epicarpo de macaúba.

macaúba epicarp presented higher bulk density and expressed a good residue energy quality. One of the major limitations of using biomass as a feedstock for bioenergy products is its low bulk density, which usually ranges from $80-150 \mathrm{~kg} \cdot \mathrm{m}^{-3}$ for agricultural residues and grasses and $150-250 \mathrm{~kg} . \mathrm{m}^{-3}$ for woody resources such as wood, chips or sawdust. Therefore, it is desirable that lignocellulosic residues present higher values of bulk density, since this has a direct influence on transportation costs and energy density, which are determining factors in the feasibility of using renewable energies (Tumuluru et al., 2011).

Although the biomasses presented high values of PCS, a higher value of this variable was observed for pine wood $(5088 \mathrm{kcal} / \mathrm{kg})$. Possibly, this behavior can be verified due to the pine being a conifer, in this sense, it presents higher amounts of fixed carbon, high lignin and resin contents and, consequently, upper calorific value (Shulga et al., 2008). An example of this was found in the study by Pallavi et al. (2013), which verify species of conifers with high resin content, such as Pinus sylvestris, whose wood has a calorific value superior of $4636 \mathrm{kcal} / \mathrm{kg}$. The high concentrations of fixed carbon and high lignin contents in the macaúba epicarp favor its high PCS. Evaristo (2015) found the PCS mean value equivalent to $4.826 \mathrm{kcal} / \mathrm{kg}$ for fruit epicarp macaúba, a similar value obtained in this work (4863 kcal/kg).

According to McKendry (2002) quoted by Souza and Vale (2016), the reaction of the biomass for burning is related to the content of volatile materials, namely the ease of ignition of the biomass due to volatilization of the material substances during heating. Although the content of volatile materials of pine wood was higher, it did not differ statistically from the values observed for the epicarp. The average values determined for volatiles and fixed carbon in the Pinus sp. waste are close to those found by Brito; Barrichelo (1982), who mentioned that the volatile contents of the wood are between $75 \%$ to $85 \%$ and the fixed carbon between $15 \%$ to $25 \%$.

In relation to the ash content, these negatively affect the calorific value of the biomass and increase the frequency of cleaning ashtray furnaces, due to the increased production of ash, as well as entail corrosion and the fouling of the metals used in the construction of the combustion system (Vital et al., 2013).

The ash content obtained for the macaúba epicarp $(3.8 \%)$ was similar to that found by Evaristo et al. (2016), evaluating the energetic potential of the different macaúba residues. The epicarp was found to be $5.66 \%$ and the endocarp $2.04 \%$. The $0.44 \%$ ash content observed for the particles of Pinus sp. is in line with that normally found for different types of wood. Bufalino et al. (2012) found values of $0.32 \%$ 
for wood ash in the Australian cedar (Toona ciliata), while Barcellos et al. (2005) had a content of ashes of $0.6 \%$ in Eucalyptus grandis. The variation of ash content may be related to the origin of the species.

Although the macaúba epicarp is considered suitable for use as a solid biofuel, its ash content is considered high. However, briquettes constructed with larger proportions of Pinus sp. tend to decrease its ash content. As the study by Fernandéz-Puratich et al. (2017) that produced pellets of corn dust and Pinus radiata under different proportions (ash content: $2.7 \%$ and $0.7 \%$, respectively). The authors verified that for those biofuels with higher concentration of Pinus radiata, lower ash content was obtained.

The fixed carbon content is the mass remaining after the releases of volatiles, excluding the ash and moisture contents (Mckendry, 2002) and it is inversely proportional to the content of volatile materials (Oliveira et al., 2010). Pinus sp. presented a fixed carbon content of $10.5 \%$. It is verified that the average percentage of fixed carbon found for the macaúba epicarp (13.3\%) was higher or close to several agricultural and wood residues used for energy generation. The fixed carbon of macaúba fruit processing residues is higher or near various agricultural and wood residues used for energy production, evidencing the potential of macaúba waste for energy generation.

When studying the combustion properties of briquettes in different proportions of rice husk and palm oil mill sludge, Obi and Okongwu (2016) found a fixed carbon percentage of $11.95 \%$ in $1: 10$ bending ratio, similar to that found in the present study for macaúba palm. Evaristo et al., (2016), when analyzing the macaúba fruit potential to produce solid biofuels, found a fixed average carbon value for the epicarp of $16.12 \%$.

The apparent density is a parameter of great importance in the assessment of the quality of the briquettes, since it directly influences the transportation and energy density of the same. In addition, a material with high apparent density facilitates the storage conditions (Rodrigues, 2010).

Scalet (2015) aimed at increasing the use of the Licuri palm bark - commonly found in the Brazilian semiarid region - as a fuel source, by studying briquettes in different proportions of this residue, combined with sugarcane straw, obtaining average values for apparent density of 1.033 g.cm ${ }^{-3}$, which is a similar value, however, lower than those found for the briquettes produced only with macaúba epicarp $\left(1.13 \mathrm{~g} . \mathrm{cm}^{-3}\right)$.

An apparent density value was obtained for briquettes produced from the coconut shell of $0.98 \mathrm{~g} . \mathrm{cm}^{-3}$, where these results referred to the literature data show that the briquettes produced have a relatively good density, which is important in the logistic aspect (Dziedzic et al., 2018). In general, there is a tendency to increase the apparent density with the increase of the epicarp percentage in the composition of the briquettes particles. This is due to higher bulk density of the epicarp of the macaúba palm regarding wood Pinus sp., which have a larger amount of mass per unit volume.

The useful calorific value takes into account the higher calorific value and the amount of water present in the material (Freitas et al., 2016). Therefore, considering the values in real terms, the amount of energy in the form of heat released by the combustion of the epicarp and Pinus sp. wood, averages 4174.5 $\mathrm{kcal} / \mathrm{kg}$ and $4321.1 \mathrm{kcal} / \mathrm{kg}$ were obtained respectively, finding greater value to the wood of Pinus sp. Possibly, this behavior was observed due to the higher value of the gross calorific value of Pinus sp.

Thus, the energy density is related to the useful calorific value and the apparent density of the biomasses. It was observed that there were significant differences between the materials for this variable, indicating a higher value for the macaúba epicarp. Probably, this behavior was observed due to the higher values of apparent density for the briquettes produced with macaúba epicarp.

It should be noted that materials with low energy density may not be feasible in terms of their use, since they may increase transport costs, as more material is needed for a good energy yield, as well as contributing negatively to the energy balance in the combustion reaction (Quirino, 2002).

The addition of up to $50 \%$ macaúba epicarp composition of the particles for the production of briquettes resulted in an increase in resistance thereof, however, by increasing larger amounts of particles of Pinus sp. woods. In the manufacturing of the briquettes, we observed a tendency toward a decrease in the resistance. This effect is probably due to the fact

Revista Árvore 2019;43(5):e430501 
the residue of Pinus sp. has lower values of apparent density, which corroborates with a lower resistance to this biomass.

\section{CONCLUSION}

Despite the good energy characteristics of the epicarp of macaúba, Pinus sp. waste is characterized by a higher calorific value and lower ash content;

Treatments 1 and 2, corresponding to $100 \%$ macaúba and macaúba $75 \%+25 \%$ pine, respectively, have the highest mean values of apparent density and energy density;

The briquettes with high proportions of macaúba epicarp in their composition have higher resistance compared to compositions with high briquettes Pinus sp;

The use of macaúba palm waste for making briquettes is feasible and provides greater resistance and energy density to the product, promoting its use associated with briquettes made from Pinus sp. waste. The use of briquettes in larger proportions of the macaúba epicarp is recommended in order to lower production costs in the production chain briquettes manufactured from Pinus sp.;

It is technically feasible to take advantage of macaúba palm waste and Pinus sp. for the production of briquettes.

\section{ACKNOWLEDGMENTS}

The authors of this paper would like to offer their thanks to the Panels and Wood Energy Laboratory for their trust in our carrying out this research, and to the partner institutions for their support: Federal University of Rio Grande do Norte (UFRN), Federal University of Viçosa (UFV) and the Federal University of São João Del Rei (UFSJ) and finally to the National Council for Scientific and Technological Development (CNPq) for the financial support.

\section{REFERENCES}

American Society for Testing and Materials. Standard method for chemical analysis of charcoal. Philadelphia. 1982. 1042 p.

Associação Brasileira de Normas Técnicas - ABNT. NBR 11941: Madeira - Determinação da densidade básica. Rio de Janeiro: 2003.
Associação Brasileira de Normas Técnicas - ABNT. NBR 7190: Projeto de estrutura de madeira. Rio de Janeiro: 1997.

Associação Brasileira de Normas Técnicas - ABNT. NBR 8112: Carvão vegetal - Análise imediata Método de ensaio. Rio de Janeiro: 1986.

Associação Brasileira de Normas Técnicas - ABNT. NBR 8633: Carvão vegetal - Determinação do poder calorífico - Método de ensaio. Rio de Janeiro: 1984.

Barcellos DC, Couto LC, Müller MD, Couto L. O estado-da- arte da qualidade da madeira de eucalipto para a produção de energia: um enfoque nos tratamentos silviculturais. Biomassa \& Energia. 2005;2(2):141-58.

Brito JO, Barrichelo LEG, Muramoto MC, Couto HTZ. Estimativa da densidade a granel do carvão vegetal a partir de sua densidade aparente. Instituto de Pesquisas e Estudos Florestais. Circular Técnica $\mathrm{n}^{\circ} 150 ; 1982$. ISSN0100-3453.

Bufalino L, Protásio TP, Couto AM, Nassur OAC, Sá VA, Trugilho PF, et al. Caracterização química e energética para aproveitamento da madeira de costaneira e desbaste de cedro australiano. Pesquisa Florestal Brasileira. 2012;32(70):129-37.

Dziedzic K, Mudryk K, Hutsol T, Dziedzic B. Impact of grinding coconut shell and agglomeration pressure on quality parameters of briquette. Engineering for rural development, 17th International Scientific Conference Engineering for Rural Development. 2018;23:1884-89. doi:10.22616/ERDev2018.17. N461.

Empresa de Pesquisa Energética - EPE. Balanço Energético Nacional 2015: ano base 2014. Rio de Janeiro: 2015. 62p.

European Standard. EN 15103: Solid biofuels Determination of bulk density. Brussels: 2010.

Evaristo AB. Conservação pós-colheita e potencial bioenergético de frutos de macaúba (Acrocomia aculeata). [tese]. Viçosa (MG): Universidade Federal de Viçosa; 2015.

Evaristo AB, Martino DC, Ferrarez AH, Donato DB, Carneiro ACO, Grossi JAS. Potencial energético dos resíduos do fruto da macaúba e sua utilização na produção de carvão vegetal. Ciência Florestal. 
2016;26(2):571-77. doi.org/10.5902/1980509822757.

Freitas AJ, Costa ACS, Oliveira AC, Pereira BLC, Rocha MFV, Carneiro ACO. Efeito da pressão e do tempo de compactação nas propriedades de briquetes de resíduos madeireiros de paricá. Nativa. 2016;4(6):380-85. doi.org/10.14583/2318-7670. v04n06a06.

Mckendry P. Energy production from biomass (part 1): overview of biomass. Bioresource Technology. 2002;83(1):37-46.

Mendes LM, Rabelo GF, Trugilho PF, Mori IFA. Resíduos: energia a partir de resíduos florestais. Revista da Madeira. 2004:85.

Motoike SY, Carvalho M, Pimentel LD, Kuki KN, Paes JMV, Dias HCT, et al. A Cultura da Macaúba: implantação e manejo de cultivos racionais. Viçosa, MG: Ed. UFV, 2013. ISBN13 978-8572694742.

Obi OF, Okongwu KC. Characterization of fuel briquettes made from a blend of rice husk and palm oil mill sludge. Biomass Conv. Bioref. 2016;6(4):449-56. doi: 10.1007/s13399-016-0206-x

Oliveira AC, Carneiro ACO, Vital BR, Almeida W, Pereira BLC, Cardoso MT. Parâmetros de qualidade da madeira e do carvão vegetal de Eucalyptus pellita F. Muell. Scientia Forestalis. 2010;38(87):431-39.

Pallavi HV, Srikantaswmy S, Kiran BM, Vyshnavi DrCh, Ashwin CA. Briquetting Agricultural Waste as an Energy Source. Journal of Environmental Science, Computer Science and Engineering and Technology. 2013;2:160-72.

Protásio TP, Alves ICN, Trugilho PF, Silva VO, Baliza AER. Compactação de biomassa vegetal visando à produção de biocombustíveis sólidos. Pesquisa Florestal Brasileira. 2011;31(68):273-83. doi: $10.4336 / 2011 . p f b .31 .68 .273$.

Quirino WF. Utilização energética de resíduos vegetais. IBAMA, Laboratório de Produtos Florestais - LPF, Brasília. 2002, 35 p.

Rodrigues VAJ. Valorização energética de lodo biológico da indústria de polpa celulósica através da briquetagem. [dissertação]. Viçosa (MG):

Universidade Federal de Viçosa; 2010.

Scalet V. Caracterização e confecção de briquetes da casca de Licuri (Syagrus coronata (Mart) Becc.) para produção de energia. [dissertação]. Sorocaba (SP): Universidade Federal de São Carlos, Campus Sorocaba; 2015.

Shulga G, Betkers T, Brovkina J, Aniskevicha O, Ozolins J. Relationship between Composition of the lignin-based interpolymer complex and its Structuring ability. Environ Eng Manag J. 2008;7(4):397-00. doi:10.30638/eemj.2008.056.

Silva CA. Estudo técnico-econômico da compactação de resíduos madeireiros para fins energéticos. [dissertação]. Campinas (SP): Faculdade de Engenharia Mecânica - Universidade Estadual de Campinas; 2007.

Souza F, Vale AT. Densidade energética de briquetes de biomassa lignocelulósica e sua relação com os parâmetros de briquetagem. Pesq. flor. bras. 2016;36(88):405-13.

STATSOFT, Inc. Statistica (data analysis software system), version 8. Software Estatístico; 2009.

Tolmasquim MT, Guerreiro A, Gorini R. Matriz energética brasileira: uma prospectiva. Novos estudos. 2007;79:47-69. doi.org/10.1590/S010133002007000300003 .

Tumuluru JS, Wright CT, Hess JR, Kenney KL. A review of biomass densification systems to develop uniform feedstock commodities for bioenergy application. Biofuels, Bioproducts and Biorefining. 2011;5(6):683-07. doi.org/10.1002/ bbb.324.

VITAL BR, Carneiro ACO, Pereira BLC. Qualidade da madeira para fins energéticos. In: Santos F, Colodette J, Queiroz JH. (Org.). Bioenergia \& Biorrefinaria: Cana-de-Açúcar \& Espécies Florestais. Viçosa, MG: Os editores, 2013. 